\title{
Kinetics and Thermodynamic Studies of the Arsenite Oxidation by K-OMS2
}

\author{
Jakkapop Phanthasri, Bhuckchanya Pangkumhang, Panitan Jutaporn, and Visanu Tanboonchuy
}

\begin{abstract}
Manganese octahedral molecular sieve or cryptomelane (K-OMS2) was synthesized by hydrothermal method and tested as catalytic oxidation of arsenite at different temperatures. The synthesized K-OMS2 was characterized by X-ray diffraction (XRD), Point of zero charge (pHpzc), and Brunauer Emmett Teller (BET). The results showed that K-OMS2 has cryptomelane crystalline structure, $\mathrm{pHpzc} \approx 5$, and high surface area of $134.76 \mathrm{~m} 2 \mathrm{~g}-1$. The results showed that the catalytic oxidation could completely oxidize arsenite to arsenate and the oxidation rate increased as temperature increased in the range of temperature investigated $(303-333 \mathrm{~K})$. The oxidation kinetic of arsenite fitted well with the pseudo-second-order kinetic model. The oxidation process occurred spontaneously $\left(-\Delta G^{\circ}\right)$, in an endothermic nature $\left(+\Delta H^{\circ}\right)$, and with increased randomness $\left(+\Delta S^{\circ}\right)$. The overall result suggested the potential use of K-OMS2 as a catalytic for the oxidation of arsenite.
\end{abstract}

Index Terms-Arsenic, oxidation, manganese oxide octahedral molecular sieves, K-OMS2.

\section{INTRODUCTION}

The contamination of arsenic in groundwater is a worldwide problem in Thailand, North America, India and some European countries because arsenic is toxic and carcinogenic [1]. Long-term uptake of arsenic contaminated water can lead to liver, lung, kidney, bladder, and skin cancer [2]. Recently, arsenic contamination in drinking water has been reported. The World Health Organization set provisional guideline for arsenic in drinking water standard at $10 \mathrm{ppb}$ [3]. Common forms of arsenic in natural water were arsenite ( $\mathrm{As}(\mathrm{III}), \mathrm{H}_{3} \mathrm{AsO}_{3}, \mathrm{H}_{2} \mathrm{AsO}_{3}{ }^{-}$and $\mathrm{HAsO}_{3}{ }^{2-}$ ), mainly found in reducing condition, and arsenate $\left(\mathrm{As}(\mathrm{V}), \mathrm{H}_{3} \mathrm{AsO}_{4}\right.$, $\mathrm{H}_{2} \mathrm{AsO}_{4}{ }^{-}$and $\mathrm{HAsO}_{4}{ }^{2-}$ ), a form stable in oxidizing state [4], [5]. Since As(III) is much more toxic and more transportable than $\mathrm{As}(\mathrm{V})$, it is necessary to oxidize $\mathrm{As}(\mathrm{III})$ to $\mathrm{As}(\mathrm{V})$ in the treatment of arsenic.

Variety of methods such as oxidation, adsorption, precipitation, co-precipitation, ion-exchange, ultra-filtration, and reverse osmosis have been used for arsenic removal. The adsorption method was effective for $\mathrm{As}(\mathrm{V})$, but not as successful in case of As(III) [6]. The oxidation process is considered one of the more promising technologies because

Manuscript received January 11, 2017; revised May 5, 2017. This work was supported by Department of Environmental Engineering, Faculty of Engineering, Khon Kaen University, Khon Kaen, 40002, Thailand and Research Center for Environmental and Hazardous Substance Management (EHSM), Khon Kaen University, Khon Kaen, 40002, Thailand.

J. Phanthasri, B. Pangkumhang, P. Jutaporn, and V. Tanboonchuy are with the Department of Environmental Engineering, Faculty of Engineering, Khon Kaen University, 40002, Thailand (e-mail: jakkapop@kkumail.com, bhuckchanya@gmail.com, panitju@kku.ac.th, and visanu@kku.ac.th). the system is simple and cost-effective [7]. To achieve greater arsenic removal, a pretreatment for As (III) oxidation is usually employed, followed by co-precipitation/adsorption of the As (V).

Many oxidants or oxidant-generating systems have been tested for the oxidation of As (III). For example, manganese oxides [8], $\mathrm{O}_{2}$ and/or ozone [9], hydrogen peroxide [10] and $\mathrm{TiO}_{2} / \mathrm{UV}$ systems [11]. More specifically, manganese dioxide was effective as an oxidizing agent of As(III) [12]. The oxidation potential of $\mathrm{MnO}_{2}$ was relatively low and fit for specific oxidation of As(III). Manganese dioxide could also be used as adsorbent for removal arsenic, but its adsorption capacity was low thus limiting its application [13].

Previous studies developed a catalytic process for the oxidation of arsenite using manganese oxide octahedral molecular sieve (K-OMS2). The composition of cryptomelane materials was $\mathrm{KMn}_{8} \mathrm{O}_{16} \cdot n \mathrm{H}_{2} \mathrm{O}$ and it had tunnel-type structures consisted of $2 \times 2$ edge shared $\mathrm{MnO}_{6}$ octahedra [14]. The dimension of tunnels was reported to be $4.6 \AA \times 4.6 \AA$. Potentiometric titrations have revealed averaged average oxidation state of OMS-2 to be $\sim 3.8$, which is due to the presence of $\mathrm{Mn}^{2+}, \mathrm{Mn}^{3+}$, and $\mathrm{Mn}^{4+}$ ions in the octahedral framework. These materials are highly porous, non-toxic, environmental friendly, and had various different pore structures [15].

The objective of this study was to investigate kinetic and thermodynamic of the oxidation of As(III) to As (V) by K-OMS2. We performed the experiments with various operating parameters, such as temperature and contact time of arsenite oxidation. The kinetic and thermodynamic results were used to evaluate potential of K-OMS2 as an oxidizing agent for arsenic treatment.

\section{MethodOlOGY}

Analytical grade (99\% purity) manganese acetate tetrahydrate $\left(\mathrm{Mn}\left(\mathrm{CH}_{3} \mathrm{COO}\right)_{2} \cdot 4 \mathrm{H}_{2} \mathrm{O}\right), \quad$ potassium permanganate $(\mathrm{KMnO} 4)$ and glacial acetic acid $(\mathrm{CH} 3 \mathrm{COOH})$ were obtained from ACROS Organics, CARLO ERBA and QRëC, respectively. Stock solutions were prepared from $\mathrm{NaAsO}_{2} \quad$ (Sigma) and $\mathrm{Na}_{2} \mathrm{HAsO}_{4} \quad 7 \mathrm{H}_{2} \mathrm{O} \quad$ (Sigma), Determination of individual arsenic species were conducted using Anion-exchange cartridge, A502P (Purolite).

\section{A. K-OMS2 Synthesis}

A fixed mole ratio of $0.75 \mathrm{KMnO}_{4} / \mathrm{Mn}\left(\mathrm{CH}_{3} \mathrm{COO}\right)_{2}$ was selected to prepare K-OMS 2. Preparation was performed as per procedure described in previous study [16] $\mathrm{Mn}\left(\mathrm{CH}_{3} \mathrm{COO}\right)_{2}$ and $\mathrm{KMnO}_{4}$ were dissolved in water separately. Then, $\mathrm{KMnO}_{4}$ solution was added dropwise to 
$\mathrm{Mn}\left(\mathrm{CH}_{3} \mathrm{COO}\right)_{2}$ solution under vigorous mixing. Then the $\mathrm{pH}$ of the solution was adjusted to an acidic condition $(\mathrm{pH} \leq 3.5)$ by glacial $\mathrm{CH}_{3} \mathrm{COOH}$ and transferred to an autoclave for hydrothermal process. In the final step, the obtained black slurry was washed and dried at $100^{\circ} \mathrm{C}$ for $4 \mathrm{hr}$ and then $200^{\circ} \mathrm{C}$ for another $2 \mathrm{hr}$ [17].

\section{B. K-OMS2 Characterization}

The formation of K-OMS 2 and its crystallinity were determined using X-ray diffractometer (Model D8 Discover, Bruker AXS Germany) using $\mathrm{CuK}_{\alpha}$ with wavelength ( $\lambda=$ $1.51418^{\circ} \mathrm{A}$ ) at $40 \mathrm{~mA}$ and $40 \mathrm{kV}$ with $2 \theta$ range of $10-80$ degrees and increasing step of 0.02 degree. The point zero of charge $\left(\mathrm{pH}_{\mathrm{pzc}}\right)$ was defined as $\mathrm{pH}$ on the charge of the adsorbent surface is zero. The $\mathrm{pH}_{\mathrm{pzc}}$ was determined according to method recommended previously [18]. A $0.1 \mathrm{M}$ solution of $\mathrm{NaCl}$ was prepared using distilled water, which was taken in different titration flasks. The $\mathrm{pH}$ of the solutions were adjusted to 2-11 using $0.1 \mathrm{M}$ of $\mathrm{HCl}$ and $0.1 \mathrm{M}$ of $\mathrm{NaOH}$ solution. $0.1 \mathrm{~g}$ of K-OMS 2 sample was added to $10 \mathrm{~mL}$ of each flask and was shaken at $150 \mathrm{rpm}$ for $48 \mathrm{hr}$ on a shaker bath. The final $\mathrm{pH}$ was measured, and plotted as a function of the initial $\mathrm{pH}$ of the solution. $\mathrm{pH}_{\mathrm{pzc}}$ was determined as the $\mathrm{pH}$ of the $\mathrm{NaCl}$ solution that does not change after the contact with the catalyst sample. The specific surface areas of the samples were measured by $\mathrm{N}_{2}$-sorption isotherm and calculated using Brunauer-Emmett-Teller (BET) method (Quantachrome, Autosorb-1).

\section{Batch Experiment}

The experiments were conducted by combining initial 5 $\mathrm{mg} / \mathrm{L}$ arsenite with $0.5 \mathrm{~g} \mathrm{~K}-\mathrm{OMS} 2$. The $\mathrm{pH}$ was adjusted by adding a small amount of dilute $\mathrm{HCl}$ or $\mathrm{NaOH}$ solution using a $\mathrm{pH}$ and ORP meter. Contact time of all experiments were in the range of 0-90 min with varied temperatures of 303-333 K. The total concentration of arsenic (As(V) and As(III)) was determined by graphite furnace atomic absorption spectroscopy (GF-AAS) (Perkin Elmer Model Analyst 800). Determination of individual arsenic species were conducted using an anion-exchange cartridge, A502P. As the arsenic-bearing water sample passed through the syringe (Syringe filter $0.45 \mu \mathrm{m})$, As(V) would be retained inside while As(III) was allowed to pass through, rendering the separation of $\mathrm{As}(\mathrm{V})$ and $\mathrm{As}(\mathrm{III})$ from each other. The eluent was then analyzed for As(III) concentration by GF-AAS. $\mathrm{As}(\mathrm{V})$ concentration was obtained by subtracting the measured $\mathrm{As}(\mathrm{III})$ concentration from total arsenic concentration.

\section{Kinetic Models}

Kinetic models have been proposed to understand the mechanism and to scale-up the efficiency of the oxidation process [19]. In order to investigate the potential rate determining step such as pseudo first order, and pseudo second order kinetic models, the experimental data were tested [20]. The linear form of pseudo first order equation is given by

$$
\ln \left(q_{e}-q_{t}\right)=\ln q_{e}-k_{1} t
$$

The linear form of pseudo second order model is given by

$$
\frac{t}{q_{t}}=\frac{1}{k_{2} q_{e}^{2}}+\frac{t}{q_{e}}
$$

where $q_{e}$ and $q_{t}$ are the amounts of As(III) oxidized by $\mathrm{K}-\mathrm{OMS} 2$ at equilibrium and at various time $\mathrm{t}\left(\mathrm{mg} \cdot \mathrm{g}^{-1}\right) ; k_{1}$ is the equilibrium rate constant of pseudo first order kinetics $\left(\min ^{-1}\right) ; t$ is the contact time (min); and $k_{2}$ is the equilibrium rate constant of the pseudo second order kinetics $\left(\mathrm{g} \cdot \mathrm{mg}^{-1} \mathrm{~min}^{-1}\right)$ [21].

\section{E. Thermodynamic Parameters}

The thermodynamic parameters, i.e. change in the Gibbs free energy $\left(\Delta G^{\circ}\right)$, enthalpy $\left(\Delta H^{\circ}\right)$, and entropy $\left(\Delta S^{\circ}\right)$, are calculated to evaluate the thermodynamic feasibility and the nature of the oxidation process. $\Delta G^{\circ}$ can be calculated according to the following equation:

$$
\Delta G^{\mathrm{o}}=-R T \ln k_{d}
$$

where $R$ is the gas constant $\left(8.314 \mathrm{~J} \cdot \mathrm{mol}^{-1} \mathrm{~K}^{-1}\right)$; $\mathrm{T}$ is the temperature $(K)$ : and $k_{d}$ is the thermodynamic equilibrium constant of the oxidation process, reflecting arsenic distribution between the solid and liquid phases at equilibrium. Equilibrium constant $\left(k_{d}\right)$ is estimated as:

$$
k_{d}=q_{e} / C_{e}
$$

According to the van't Hoff equation:

$$
\ln k_{d}=\frac{\Delta S^{o}}{R}-\frac{\Delta H^{o}}{R T}
$$

The values of $\Delta H^{\circ}\left(\mathrm{kJ} \cdot \mathrm{mol}^{-1}\right)$ and $\Delta S^{\circ}\left(\mathrm{J} \cdot \mathrm{mol}^{-1} \mathrm{~K}^{-1}\right)$ were evaluated from the slope and intercept of van't Hoff plots [22].

\section{RESULTS AND DISCUSSION}

\section{A. K-OMS2 Characterization}

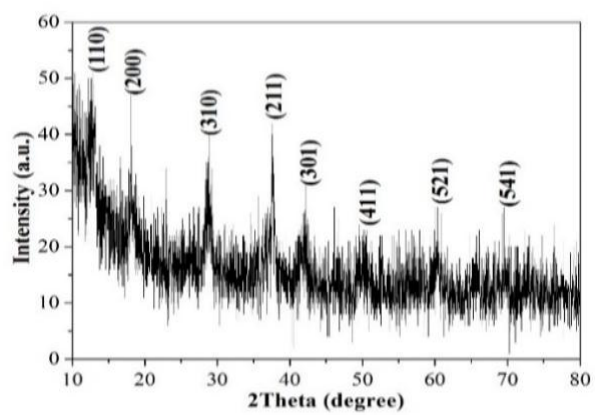

Fig. 1. XRD pattern of K-OMS2.

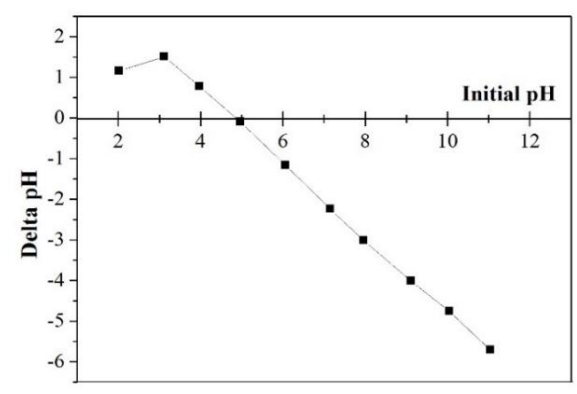

Fig. 2. Point of zero charge of K-OMS2.

The X-ray diffraction patterns of K-OMS2 prepared by 
hydrothermal method are showed in Fig. 1. All peaks can be indexed to pure cryptomelane phase (JCPDS 29-1020) [23]. In order to determine the variation of the surface charge of K-OMS2 as a function of $\mathrm{pH}$, point zero of charge measurements at different $\mathrm{pH}$ were carried out. As shown in Fig. 2, the point zero of charge of K-OMS2 is 5. Thus, pH greater than 5 leads to the surface possessing negative charges, while $\mathrm{pH}$ lower than $\mathrm{pH} 4$ results in positive charge at the surface of catalyst. The specific surface area is $134.76 \mathrm{~m}^{2} \mathrm{~g}^{-1}$.

\section{B. Kinetic of Arsenite Oxidation by K-OMS2}

The kinetics of As(III) oxidation by K-OMS2 in a temperature range of 303-333 $\mathrm{K}$ are illustrated in Fig. 3. It can be observed that oxidation capacity increases as contact time and temperature increase. In Fig. 4 presents the relationship between the percentage of residues of arsenic and the Oxidation Reduction Potential (ORP) compared to the time at the difference temperature. The results show that the percentage of arsenite were reduced while the percentage of arsenate and ORP values were increased. This happen as expected as K-OMS2 was an electron acceptor (oxidized). So the As(III) lost electrons and changed to As(V), resulting in increase of ORP.

To investigate the oxidation kinetics, pseudo-first-order and pseudo-second-order models were applied. Table I
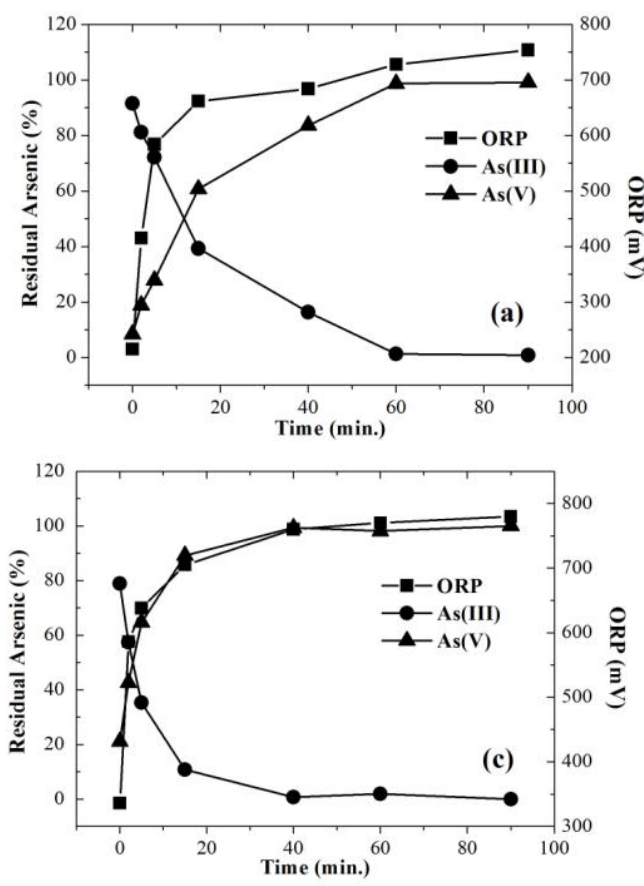

Fig. 4. The relationship between contact time and residual arsenic at (a) $303 \mathrm{~K}$ (b) $313 \mathrm{~K}$ (c) $323 \mathrm{~K}$ and (d) $333 \mathrm{~K}$.

TABLE I: KinETIC PARAMETERS FOR PSEUdO- FiRST-ORdER AND PSEUdO-SECOND-ORder KinETIC MOdELS AT DifFERENCE TEMPERATURE

\begin{tabular}{|c|c|c|c|c|c|c|}
\hline \multirow{2}{*}{$T(\mathrm{~K})$} & \multicolumn{3}{|c|}{ Pseudo-first-order } & \multicolumn{3}{|c|}{ Pseudo-second-order } \\
\hline & $k_{1}\left(\min ^{-1}\right)$ & $q_{1}\left(\mathrm{mg} \cdot \mathrm{g}^{-1}\right)$ & $R^{2}$ & $k_{2}\left(\mathrm{~g} \cdot \mathrm{mg}^{-1} \min ^{-1}\right)$ & $q_{2}\left(\mathrm{mg} \cdot \mathrm{g}^{-1}\right)$ & $R^{2}$ \\
\hline 303 & 0.120 & 8.016 & 0.965 & 0.073 & 8.741 & 0.969 \\
\hline 313 & 0.145 & 7.630 & 0.964 & 0.089 & 9.141 & 0.979 \\
\hline 323 & 0.184 & 7.588 & 0.959 & 0.108 & 10.08 & 0.988 \\
\hline 333 & 0.303 & 5.448 & 0.966 & 0.253 & 8.532 & 0.997 \\
\hline
\end{tabular}

\section{Thermodynamic Study}

The results of the thermodynamic calculations in Fig. 5 are shown the linear plot of $\operatorname{lnk}_{\mathrm{d}}$ vs $1 / \mathrm{T}$, and the obtained
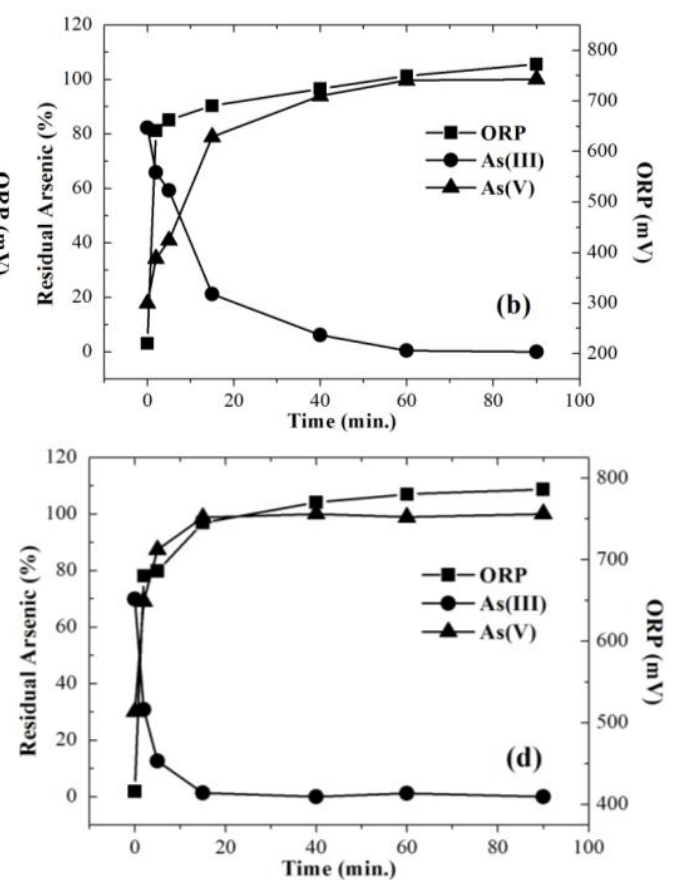

summarizes the calculated parameters of kinetic modeling. Based on the $\mathrm{R}^{2}$ value, pseudo-second-order model provided a better fit compared to the pseudo-first-order model. This indicate that the oxidation kinetic follows pseudo-second-order rate mechanism. Additionally, pseudo-second-order provided the higher values of correlation coefficient, $\mathrm{q}_{2}$ were $8.741,9.141$, and 10.08 $\mathrm{mg} \cdot \mathrm{g}^{-1}$ at 303,313 , and $323 \mathrm{~K}$, respectively. These results suggest that the overall rate constant of the As(III) oxidation was controlled by the temperature, which is consistent with the thermodynamic study.

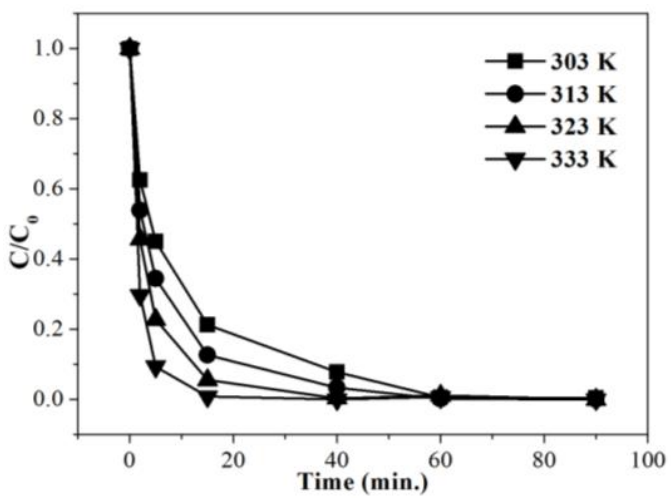

Fig. 3. The relationship between contact time and concentration of arsenic at difference temperature.

thermodynamic parameters are given in Table II. The negative value for the Gibbs free energy $\left(\Delta G^{\circ}\right)$ indicates that the oxidation process were spontaneous in nature and that the 
degree of spontaneity of the reaction decreases with increasing temperatures $(303-333 \mathrm{~K})$ [24]. The positive value of enthalpy change $\left(\Delta \mathrm{H}^{\mathrm{o}}=94.65 \mathrm{~kJ} \mathrm{~mol}^{-1} \mathrm{~K}^{-1}\right)$ confirms the endothermic nature of oxidation process. The positive value of entropy (randomness) $\left(\Delta \mathrm{S}^{\mathrm{o}}=326.37 \mathrm{~J} \mathrm{~mol}^{-1} \mathrm{~K}^{-1}\right)$ also indicates an increased randomness at the solid-liquid interface during the oxidation process [25].

TABLE II: THERMODYNAMIC PARAMETERS FOR ARSENITE OXIDATION AT DIFFERENCE TEMPERATURE BY K-OMS2

\begin{tabular}{cccc}
\hline \hline $\begin{array}{c}\text { Temperature } \\
(\mathrm{K})\end{array}$ & $\begin{array}{c}\Delta \mathrm{G}^{0} \\
\left(\mathrm{~kJ} \mathrm{~mol}^{-1}\right)\end{array}$ & $\begin{array}{c}\Delta \mathrm{S}^{0} \\
\left(\mathrm{~J} \mathrm{~mol}^{-1} \mathrm{~K}^{-1}\right)\end{array}$ & $\begin{array}{c}\Delta \mathrm{H}^{0} \\
\left(\mathrm{~kJ} \mathrm{~mol}^{-1}\right)\end{array}$ \\
\hline 303 & -5.04 & & \\
313 & -6.82 & 326.37 & 94.65 \\
323 & -9.46 & & \\
333 & -15.21 & & \\
\hline \hline
\end{tabular}

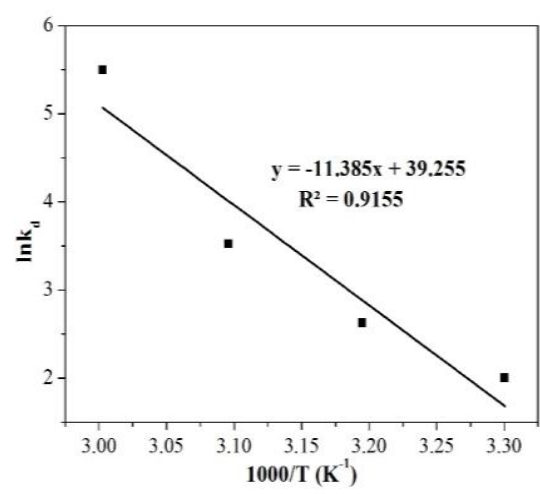

Fig. 5. The relationship between $\operatorname{lnk}_{\mathrm{d}}$ and 1000/T of arsenite oxidation by K-OMS2.

\section{CONCLUSIONS}

The K-OMS2 was synthesized by hydrothermal method and then was used as catalytic oxidation of arsenite in the temperatures range of $303-333 \mathrm{~K}$. The results showed that the catalytic oxidation could completely oxidize arsenite to arsenate and the oxidation rate increased as temperature increased in the range of temperature investigated (303 - 333 $\mathrm{K})$. The oxidation kinetic of arsenite fitted well with the pseudo-second-order kinetic model. The oxidation process occurred spontaneously $\left(-\Delta \mathrm{G}^{\circ}\right)$, in an endothermic nature $\left(+\Delta \mathrm{H}^{\circ}\right)$, and with increased randomness $\left(+\Delta \mathrm{S}^{\circ}\right)$. The overall result suggested the potential use of K-OMS2 as a catalytic for the oxidation of arsenite. Further studies on the morphology, surface elements distribution, and oxidation states of K-OMS2 should be done for a better understanding on the mechanism of the K-OMS2 catalytic in arsenite oxidation process.

\section{ACKNOWLEDGEMENTS}

This work was financial supported by the young researcher development project of Khon Kaen University, the Research Center for Environmental and Hazardous Substance Management (EHSM), Khon Kaen University, the Khon Kaen University's Graduate Research Fund Academic Year 2016.

\section{REFERENCES}

[1] V. K. Sharma and M. Sohn, "Aquatic arsenic: toxicity, speciation, transformations, and remediation," Environ. Int., vol. 35, no. 4, pp. 743-59, May 2009.
[2] D. Mohan and C. U. Pittman, "Arsenic removal from water/wastewater using adsorbents--A critical review," J. Hazard. Mater., vol. 142, no. 1-2, pp. 1-53, Apr. 2007.

[3] A. P. Howe, M. Hughes, E. Kenyon, D. R. Lewis et al., Environmental Health Criteria 224 Arsenic and Arsenic Compunds, 2nd ed., 2001, pp. $1-66$.

[4] S. Wang and C. N. Mulligan, "Speciation and surface structure of inorganic arsenic in solid phases: A review," Environ. Int., vol. 34, no. 6, pp. 867-879, 2008.

[5] U. Shafique et al., "Removal of arsenic from water using pine leaves," J. Taiwan Inst. Chem. Eng., vol. 43, no. 2, pp. 256-263, 2012.

[6] W. Driehaus, R. Seith, and M. Jekel, "Oxidation of arsenate(III) with manganese oxides in water treatment," Water Res., vol. 29, no. 1, pp. 297-305, 1995.

[7] M. Jang, S.-H. Min,T.-H. Kim, and J. K. Park, "Removal of arsenite and arsenate using hydrous ferric oxide incorporated into naturally occurring porous diatomite," 2006.

[8] Y. Wu, W. Li, and D. L. Sparks, "The effects of iron(II) on the kinetics of arsenic oxidation and sorption on manganese oxides," J. Colloid Interface Sci., vol. 457, pp. 319-328, 2015.

[9] M.-J. Kim and J. Nriagu, "Oxidation of arsenite in groundwater using ozone and oxygen," Sci. Total Environ., vol. 247, no. 1, pp. 71-79, Feb. 2000.

[10] M. Pettine, L. Campanella, and F. J. Millero, "Arsenite oxidation by $\mathrm{H}_{2} \mathrm{O}_{2}$ in aqueous solutions," Geochim. Cosmochim. Acta, vol. 63, no. 18, pp. 2727-2735, Sep. 1999.

[11] M. Bissen, M.-M. Vieillard-Baron, A. J. Schindelin, and F. H. Frimmel, " $\mathrm{TiO}_{2}$-catalyzed photooxidation of arsenite to arsenate in aqueous samples," Chemosphere, vol. 44, no. 4, pp. 751-757, Aug. 2001.

[12] D. W. Oscarson, P. M. Huang, C. Defosse, and A. Herbillon, "Oxidative power of Mn(IV) and Fe(III) oxides with respect to As(III) in terrestrial and aquatic environments," Nature, vol. 291, no. 5810, pp. 50-51, May 1981.

[13] V. Lenoble, C. Laclautre, B. Serpaud, V. Deluchat, and J.-C. Bollinger, "As(V) retention and As(III) simultaneous oxidation and removal on a $\mathrm{MnO}_{2}$-loaded polystyrene resin," Sci. Total Environ., vol. 326, no. 1, pp. 197-207, 2004.

[14] G. Qiu, H. Huang, S. Dharmarathna, E. Benbow, L. Stafford, and S. L. Suib, "Hydrothermal Synthesis of Manganese Oxide Nanomaterials and Their Catalytic and Electrochemical Properties," Chem. Mater. vol. 23, no. 17, pp. 3892-3901, Sep. 2011.

[15] S. Dharmarathna, C. K. King'ondu, L. Pahalagedara, C.-H. Kuo, Y. Zhang, and S. L. Suib, "Manganese octahedral molecular sieve (OMS-2) catalysts for selective aerobic oxidation of thiols to disulfides," Appl. Catal. B Environ., vol. 147, pp. 124-131, Apr. 2014.

[16] A. Yodsa-nga, J. M. Millanar, A. Neramittagapong, P. Khemthong, and K. Wantala, "Effect of manganese oxidative species in as-synthesized K-OMS 2 on the oxidation of benzene," Surf. Coatings Technol., vol. 271, pp. 217-224, Jun. 2015.

[17] J. M. Millanar, A. Yodsa-nga, P. Khemthong, and M. Daniel, "Provided with compliments of owners.org," 2013.

[18] Y. R. Lee, J. Kim, and W. S. Ahn, "Synthesis of metal-organic frameworks: A mini review," Korean J. Chem. Eng., vol. 30, no. 9, pp. 1667-1680, 2013.

[19] C. Namasivayam and R. T. Yamuna, "Adsorption of chromium (VI) by a low-cost adsorbent: Biogas residual slurry," Chemosphere, vol. 30, no. 3, pp. 561-578, Feb. 1995.

[20] M. L. Soto, A. Moure, H. Domínguez, and J. C. Parajó, "Recovery, concentration and purification of phenolic compounds by adsorption: A review," J. Food Eng., vol. 105, no. 1, pp. 1-27, 2011.

[21] Y. Ho and G. McKay, "Pseudo-second order model for sorption processes," Process Biochem., vol. 34, no. 5, pp. 451-465, 1999.

[22] W.-Y. Huang et al., "Kinetics, isotherm, thermodynamic, and adsorption mechanism studies of $\mathrm{La}(\mathrm{OH})_{3}$-modified exfoliated vermiculites as highly efficient phosphate adsorbents," Chem. Eng. J., vol. 236, pp. 191-201, 2014.

[23] I. Atribak, A. Bueno-López, A. García-García, P. Navarro, D. Frías, and M. Montes, "Catalytic activity for soot combustion of birnessite and cryptomelane," Appl. Catal. B Environ., vol. 93, no. 3, pp. 267-273, 2010.

[24] B. S. Chu, B. S. Baharin, Y. B. Che Man, and S. Y. Quek, "Separation of vitamin E from palm fatty acid distillate using silica: I Equilibrium of batch adsorption," J. Food Eng., vol. 62, no. 1, pp. 97-103, 2004.

[25] S. Tunali, T. Akar, A. S. Özcan, I. Kiran, and A. Özcan, "Equilibrium and kinetics of biosorption of lead(II) from aqueous solutions by Cephalosporium aphidicola," Sep. Purif. Technol., vol. 47, no. 3, pp. 105-112, 2006. 


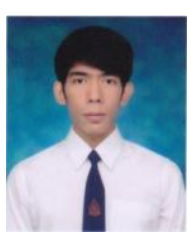

Jakkapop Phanthasri is a master degree student in the Department of Environmental Engineering, Faculty of Engineering, Khon Kaen University, Thailand.

Mr. Jakkapop Phanthasri is interested in nano-material synthesis, waste water treatment and characterization of material.

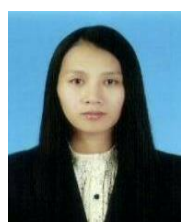

Bhuckchanya Pangkumhang is a doctoral degree student in the Department of Environmental Engineering, Faculty of Engineering, Khon kaen University, Thailand. Ms. Bhuckchanya Pangkumhang is interested in metal-organic frameworks, nano-materials, wastewater treatment, and application of materials.

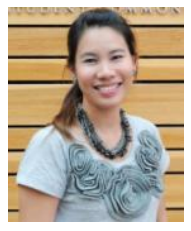

Panitan Jutaporn is a lecturer at the Department of Environmental Engineering, Faculty of Engineering, Khon Kaen University, Thailand. Mrs. Panitan Jutaporn is interested in Membrane technology, Waste water treatment, ion exchange resin and Energy.

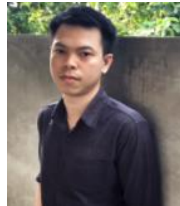

Visanu Tanboonchuy is a lecturer at the Department of Environmental Engineering, Faculty of Engineering, Khon Kaen University, Thailand. Mr. Visanu Tanboonchuy is interested in nano-material synthesis, groundwater treatment, waste water treatment, adsorption, kinetic model and energy. 